\title{
PANDEMI CORONA SEBAGAI ALASAN PEMUTUSAN HUBUNGAN KERJA PEKERJA OLEH PERUSAHAAN DIKAITKAN DENGAN UNDANG-UNDANG KETENAGAKERJAAN
}

\author{
Yusuf Randi \\ Fakultas Hukum Universitas Padjadjaran \\ Jl. Raya Bandung Sumedang KM. 21 Jatinangor, Kabupaten Sumedang, Jawa Barat, 45363 \\ Email : yusuf13randi@gmail.com
}

\begin{abstract}
Corona pandemic has an impact on almost all fields including employment. Financial difficulties faced by the company have implications for the emergence of layoffs as a reason for efficiency or force majeure reasons. This paper presents two main problems. First, can the corona pandemic be used as a reason for layoffs by the company? second, how is the protection of workers' rights terminated by the company according to the Manpower Act? Through a juridical normative study, an explanation was obtained that employers could use the corona pandemic as a reason for force majeure to lay off because of influencing the company's finances and obligations to workers; an unexpected event; and corona as a non-natural disaster on a national scale. In addition to force majeure reasons, efficiency is also a reason for layoffs. Layoffs due to force majeure reasons to give birth to workers 'rights by Article 164 paragraph (1), whereas if dismissals are due to efficiency reasons, then workers' rights are by with Article 164 paragraph (3) of the Manpower Act.
\end{abstract}

Key words: Corona Pandemic, Layoffs, Force Majeure, Efficiency

\begin{abstract}
ABSTRAK
Pandemi corona berdampak terhadap hampir seluruh bidang termasuk ketenagakerjaan. kesulitan keuangan yang dihadapi perusahaan berimplikasi terhadap munculnya tindakan pemutusan hubungan kerja (PHK) sebagai alasan efisiensi maupun alasan force majure. Tulisan ini menyajikan dua masalah pokok. Pertama, apakah pandemi corona dapat dijadikan sebagai alasan pemutusan hubungan kerja pekerja oleh perusahaan? Bagaimana perlindungan hak pekerja yang diputus hubungan kerjannya oleh perusahaan menurut UU Ketenagakerjaan? Melalui kajian secara yuridis normatif, diperoleh penjelasan bahwa pengusaha dapat menggunakan pandemi corona sebagai alasan force majeure untuk melakukan PHK karena: berpengaruh terhadap keuangan dan kewajiban perusahaan kepada pekerja; merupakan peristiwa yang sifatnya tidak terduga; serta corona sebagai bencana nonalam berskala nasional. Selain alasan force majeure, efisiensi juga menjadi alasan untuk melakukan PHK. PHK karena alasan force majeure melahirkan hak bagi pekerja sesuai ketentuan Pasal 164 ayat (1), sedangkan bila PHK karena alasan efisiensi, maka hak pekerja sesuai ketentua Pasal 164 ayat (3) UU Ketenagakerjaan.
\end{abstract}

Kata kunci: Pandemi Corona, Pemutusan Hubungan Kerja, Force Majeure, Efisiensi

\section{PENDAHULUAN}

Diawal tahun 2020, dunia digemparkan dengan merebaknya virus baru yaitu corona virus jenis baru (Sars-Cov) dan penyakitnya disebut corona virus diasease 2019 (Covid19). ${ }^{1}$ Kasus pertama mengenai Covid-19 (selanjutnya disebut virus corona) ini dilaporkan pada 31 Desember 2019, di

\footnotetext{
1 Yuliana ,(2020, Februari), Corona Virus disease (Covid-19); Sebuah Tinjauan Literatur, Wellness and healthy
} magazine, Volume 2, Nomor 1, hlm. 1. 
Wuhan, Cina. Tetapi hingga saat ini belum diketahui dengan jelas asal mula dari virus corona tersebut.

Pandemi virus corona tak hanya mengguncang Wuhan, tetapi juga dunia. Virus ini telah menyebar secara luas hampir ke seluruh negara dalam waktu yang singkat. Jumlah kasus infeksi virus corona diseluruh dunia hingga Jumat 17 April 2020 mencapai 2.179.905 orang. Data yang dirilis situs pelaporan online worldometer menunjukkan korban meninggal akibat virus corona sebanyak 145.410 jiwa, dan 546.743 pasien dinyatakan sembuh. ${ }^{2}$

Sementara itu, di Indonesia virus corona mulai terdeteksi masuk ketika dua warga negara Indonesia (WNI) dinyatakan positif virus corona pada 1 Maret 2020. Kedua WNI itu sebelumnya pernah berkontak dengan seorang warga negara asing (WNA) asal Jepang yang tinggal di Malaysia pada suatu acara di Jakara. Berdasarkan data sampai dengan 20 April 2020 korban akibat virus corona berjumlah 6.760 kasus. Sebanyak 590 di antaranya meninggal dunia dan 747 orang dinyatakan sembuh. ${ }^{3}$
Pemerintah Indonesia sendiri telah menetapkan virus corona sebagai jenis penyakit yang menimbulkan kedaruratan kesehatan masyarakat. Oleh karena itu, dalam rangka menghambat penyebaran virus corona, Pemerintah mengambil langkah dengan menetapkan pandemi virus corona sebagai bencana nasional dan mengimbau masyarakat untuk melakukan physical distancing serta belajar/bekerja dari rumah (work from home). Imbauan pemerintah ini diikuti dengan dikeluarkannya sejumlah payung hukum yang sejatinya dimaksudkan untuk menekan penyebaran virus corona. ${ }^{4} \mathrm{Di}$ sisi lain, physical distancing dan pembatasan aktivitas tersebut secara tidak langsung membuat aktivitas-aktivitas masyarakat yang menimbulkan kerumunan, seperti aktivitas pendidikan di sekolah, pekerjaan di perusahaan, kegiatan di ruang umum, hingga keagamaan di rumah ibadah berkurang secara signifikan.

Salah satu sektor yang sangat terdampak dari pandemi corona ini adalah ketenagakerjaan. Meluasnya penyebaran virus corona hampir di seluruh wilayah

\footnotetext{
2 __, (17/4/2020), Update Corona Global: 2,1 Juta Terinfeksi, 546 Ribu Sembuh, Di akses pada tanggal 20 April 2020, pukul 22:24 WIB., https://www.cnnindonesia.com/internasional/20200417065915-113-494382/update-corona-global-21-jutaterinfeksi-546-ribu-sembuh.

3 __ (20/4/2020), Update Corona 20 April: 6.760 Positif, 747 Sembuh, Di akses pada tanggal 20 April 2020, pukul 22:52 WIB., CNN Indonesia, https://www.cnnindonesia.com/nasional/20200420133516-20495244/update-corona-20-april-6760-positif-747-sembuh.

4 Siregar, Putra, PM \& Ajeng Hanifa Zahra, (15/4/2020), Bencana Nasional Penyebaran COVID-19 sebagai Alasan Force Majeure, Apakah Bisa?, Di akses pada tanggal 21 April 2020, pukul 16;20 WIB.,Direktorat Jenderal Kekayaan Negara, Kementrian Keuangan, https://www.djkn.kemenkeu.go.id/artikel/baca/13037/Bencana-Nasional-Penyebaran-COVID-19-sebagaiAlasan-Force-Majeure-Apakah-Bisa.html.
} 
Indonesia sangat mempengaruhi kinerja, produktivitas, keuangan perusahaan maupun kewajiban pengusaha untuk memenuhi kebutuhan biaya operasional salah satunya membayar hak-hak normatif pekerja seperti upah. Disamping itu, adanya pembatasan aktivitas dan himbauan untuk bekerja dari rumah (work from home) menimbulkan suatu masalah baru bagi perusahaan mengingat tidak semua jenis pekerjaan bisa dikerjakan di rumah oleh pekerja.

Sebagian perusahaan yang mengalami kesulitan keuangan tersebut kemudian mendorong pengusaha mengeluarkan beberapa kebijakan yang merugikan pekerja/buruh diantaranya adanya praktik unpaid leave (mencutikan pekerjanya, namun tidak dibayar), merumahkan pekerja, dan bahkan berujung pada pemutusan hubungan kerja (PHK) yang dilakukan pengusaha kepada pekerjanya secara sewenang-wenang.

Sementara itu, Menteri Ketenagakerjaan Ida Fauziyah mengingatkan seluruh perusahaan dan dunia usaha untuk menjadikan PHK sebagai langkah terakhir dalam menghadapi dampak pandemi virus corona. $^{5}$ Menteri Ketenagakerjaan Ida Fauziyah mengungkapkan data per-20 April 2020, jumlah pekerja yang terdampak Covid19 total sebanyak 2.084 .593 pekerja dari sektor formal dan informal yang berasal dari 116.370 perusahaan. $^{6}$ Adapun jumlah pekerja formal yang di-PHK sebanyak 241.431 orang pekerja dari 41.236 perusahaan.

Pemutusan Hubungan Kerja (PHK) merupakan suatu hal yang sangat ditakuti oleh karyawan. Hal ini dikarenakan carut marutnya kondisi perekonomian yang berdampak pada banyak perusahaan yang harus gulung tikar, dan tentu saja berdampak pada pemutusan hubungan kerja yang dilakukan secara sepihak oleh pengusaha. ${ }^{7}$ Umar Kasim juga menjelaskan bahwa PHK merupakan isu yang sensitif, pengusaha seharusnya bijaksana dalam melakukan PHK, mengingat PHK dapat menurunkan kesejahteraan masyarakat, rakyat kehilangan pekerjaan, bahkan lebih gawat lagi PHK dapat mengakibatkan pengangguran. ${ }^{8}$ Sehingga apa yang diamanatkan oleh Pasal 27 ayat (2) Undang-Undang Dasar Negara

\footnotetext{
5 __ (9/4/2020), Menaker: PHK Langkah Terakhir Hadapi Dampak Covid-19, Di akses pada tanggal 23 April 2020, pukul 14:47 WIB, Hukum Online.com, .https://www.hukumonline.com/berita/baca/lt5e8edae3d0c9f/menaker--phk-langkah-terakhir-hadapidampak-covid-19/,

$6 \ldots$ _ (22/4/2020), Menaker: Badai Pasti Berlalu, Panggil Kembali Pekerja yang ter-PHK Nanti, Diakses pada tanggal 23 April 2020, pukul 14: 47 WIB., Kementrian Ketenagakerjaan Republik Indonesia, https://kemnaker.go.id/news/detail/menaker-badai-pasti-berlalu-panggil-kembali-pekerja-yang-ter-phk-nanti.

7 Maringan, Nikodemus, (2015), Tinjauan Yuridis Pelaksanaan Pemutusan Hubungan Kerja (PHK) Secara Sepihak Oleh Perusahaan Menurut Undang-Undang No. 13 Tahun 2003 Tentang Ketenagakerjaan, Jurnal Ilmu Hukum Legal Opinion, Edisi 3, Volume 3, Nomor 3, hlm. 2.

8 Kasim,Umar (__ _ _ 2004), Hubungan Kerja dan Pemutusan Hubungan Kerja, Informasi Hukum, Volume 2, hlm. 26.
} 
Republik Indonesia Tahun 1945 (selanjutnya disebut UUD 1945) bahwa tiap-tiap warga negara berhak atas pekerjaan dan penghidupan yang layak bagi kemanusiaan menjadi tidak tercapai.

Untuk melindungi hak para pekerja akibat PHK tersebut, Pemerintah sebagai salah satu unsur dalam melaksanakan hubungan industrial telah memberikan jaminan perlindungan hukum bagi pekerja yang diputus hubungan kerjanya oleh pengusaha sebagaimana diatur dalam Bab XII tepatnya pada Pasal 150-172 UndangUndang Nomor 13 Tahun 2003 Tentang Ketenagakerjaan (selanjutnya disebut UU Ketenagakerjaan).

Sebagai aturan pokok dibidang ketenagakerjaan, UU Ketenagakerjaan tidak hanya mengatur mengenai pelaksanaan hubungan industrial sejak akan terbentuknya hubungan industrial, melainkan mengatur pula mengenai berakhirnya hubungan industrial. yang dibangun antara pekerja dengan pengusaha.

Berdasarkan latar belakang masalah diatas, maka dapat dirumuskan permasalahan sebagai berikut, apakah pandemi corona dapat dijadikan sebagai alasan pemutusan hubungan kerja pekerja oleh perusahaan? bagaimana perlindungan hak pekerja yang diputus hubungan kerjanya oleh perusahaan menurut ketentuan UU Ketenagakerjaan?

Adapun penelitian ini menggunakan penelitian hukum yuridis normatif, dengan menggunakan pendekatan perundang-undangan (statute approach) dan pendekatan konseptual (conceptual approach). Penelitian ini menggunakan data sekunder berupa peraturan perundangundangan yang terkait dengan isu penelitian sebagai bahan hukum primer dan bahan hukum sekunder yang diperoleh dari literatur/buku, jurnal, artikel dan informasi dari media elektronik yang mendukung penelitian ini. Pengumpulan data tersebut diperoleh melalui studi kepustakaan dan metode analisis data yang digunakan adalah normatif kualitatif yang bertolak pada peraturan perundang-undangan sebagai norma hukum positif dengan didukung oleh hasil data sekunder lainnya. Sedangkan spesifikasi penelitian yang digunakan bersifat deskriptif analitis.

\section{PEMBAHASAN}

\section{Pandemi Corona Sebagai Alasan} Pemutusan Hubungan Kerja Pekerja Oleh Perusahaan

Hubungan kerja pada dasarnya adalah hubungan antara buruh dan majikan setelah adanya perjanjian kerja, yaitu suatu perjanjian dimana pihak kesatu, si buruh mengikatkan dirinya pada pihak lain, si majikan untuk bekerja dengan mendapatkan upah dan majikan menyatakan 
kesanggupannya untuk mempekerjakan si buruh dengan membayar upah. ${ }^{9}$

Hal ini sejalan dengan pendapat Imam Soepomo yang menyebutkan bahwa hubungan kerja terjadi setelah adanya perjanjian kerja antara buruh/pekerja dan majikan, yaitu suatu perjanjian dimana pihak kesatu, buruh, mengikatkan diri untuk bekerja dengan menerima upah pada pihak lainnya yang mengikatkan diri untuk mempekerjakan buruh itu dengan membayar upah. ${ }^{10}$

Pasal 1 angka 15 UU Ketenagakerjaan menjelaskan hubungan kerja sebagai hubungan antara pengusaha dengan pekerja/buruh berdasarkan perjanjian kerja, yang mempunyai unsur pekerjaan, upah, dan perintah. Hal ini ditegaskan pula dalam Pasal 50 UU Ketenagakerjaan yang menyebutkan bahwa hubungan kerja terjadi karena adanya perjanjian kerja antara pengusaha dan pekerja/buruh. Hubungan kerja kemudian melahirkan hak dan kewajiban yang harus dipenuhi oleh masing-masing pihak (pengusaha dan pekerja/buruh). ${ }^{11}$

Dewasa ini, masalah mengenai ketenagakerjaan sangat kompleks dan beragam. Hal tersebut dikarenakan bahwa kenyataannya hubungan kerja antara pengusaha dengan pekerja tidak selalu berjalan dengan harmonis, ${ }^{12}$ melainkan seringkali pula terjadi berbagai gejolak dan ketegangan. Ketegangan antara pekerja dan pengusaha sering memicu terjadinya perselisihan hubungan industrial, yang terkadang berakhir dengan PHK yang dilakukan oleh pengusaha terhadap pekerja. ${ }^{13}$ Semenjak meluasnya pandemi corona di Indonesia, hal ini berdampak terhadap hampir seluruh sektor antara lain kesehatan, ekonomi, industri dan sosial. Turunnya jumlah produksi otomatis menurunkan pemasukan yang diperoleh perusahaan. Akibatnya, sebagian pengusaha kesulitan mengelola keuangannya, tak terkecuali untuk memenuhi kebutuhan biaya operasional salah satunya membayar hak-hak normatif pekerja seperti upah. Kesulitan yang dihadapi tersebut kemudian mendorong pengusaha melakukan tindakan efisiensi sebagai bentuk mitigasi kerugian seperti merumahkan pekerja, dan bahkan melakukan pemutusan hubungan kerja (PHK) yang merugikan pekerja. Selain alasan efisiensi, kerugian yang dialami perusahaan akibat pandemi corona juga dinilai sebagai suatu peristiwa

\footnotetext{
9 Zainal Asikin, dkk, (2004), Dasar-Dasar Hukum Perburuhan, Jakarta: Rajagrafindo Persada, hlm. 65.

10 Soepomo, Imam, (2003), Hukum Perburuhan Bidang Hubungan Kerja, Jakarta: Djambatan, hlm. 75.

11 Randi, Yusuf, (2020, 1, Maret), Penerapan Perjanjian Bersama Berupa Pemberian Kompensasi Pemutusan Hubungan Kerja Yang Bertentangan Dengan Undang-Undang Ketenagakerjaan, Jurnal Hukum De'rechtsstaat, Volume 6, Nomor 1, hlm. 37.

12 Putra, Anak Agung Ngurah Wisnu Manika dkk,( 2018, 24, Oktober) Perlindungan Hukum Bagi Pekerja Yang Mengalami Pemutusan Hubungan Kerja Oleh Pemberi Kerja Karena Force Majeure", Kertha Semaya, Volume 5 , Nomor 1, hlm. 3.

13 Randi Yusuf, Op.Cit., hlm. 28.
} 
force majure yang kemudian menjadi alasan untuk melakukan PHK.

Perusahaan tidak serta merta dapat melakukan PHK karena mengalami kerugian, force majeure atau untuk efisiensi yang diakibatkan karena adanya pandemi dan pembatasan aktivitas yang dapat merugikan perusahaan. Dalam Pasal 164 ayat (1) UU Ketenagakerjaan menyebutkan bahwa:

"Pengusaha dapat melakukan pemutusan hubungan kerja terhadap pekerja/buruh karena perusahaan tutup yang disebabkan perusahaan mengalami kerugian secara terus menerus selama 2 (dua) tahun, atau keadaan memaksa (force majeur), dengan ketentuan pekerja/buruh berhak atas uang pesangon sebesar 1 (satu) kali ketentuan Pasal 156 ayat (2) uang penghargaan masa kerja sebesar 1 (satu) kali ketentuan Pasal 156 ayat (3) dan uang penggantian hak sesuai ketentuan Pasal 156 ayat (4)."

Berdasarkan ketentuan tersebut, dapat diketahui bahwa PHK dapat dilakukan perusahaan jika mengalami kerugian atau force majeure. PHK yang dilakukan atas alasan adanya forece majeure, sedangkan apa yang dimaksud dengan force majeure UU Ketenagakerjaan tidak menjelaskan, melainkan secara umum diatur dalam Pasal 1244 dan 1245 KUHPerdata.

Pasal 1244 KUHPerdata menjelaskan bahwa:

"Jika ada alasan untuk itu, si berutang harus dihukum mengganti biaya, rugi, dan bunga apabila ia tak dapat membuktikan, bahwa hal tidak atau tidak pada waktu yang tepat dilaksanakannya perikatan itu, disebabkan suatu hal yang tak terduga, pun tak dapat dipertanggungjawabkan padanya, kesemuanya itu pun jika itikad buruk tidaklah ada pada pihaknya."

\section{Kemudian Pasal 1245 KUHPerdata} menyebutkan:

"Tidaklah biaya rugi dan bunga, harus digantinya, apabila lantaran keadaan memaksa atau lantaran suatu kejadian tak disengaja si berutang berhalangan memberikan atau berbuat sesuatu yang diwajibkan, atau lantaran hal-hal yang sama telah melakukan perbuatan yang terlarang."

Berdasarkan ketentuan tersebut, maka unsur utama yang dapat menimbulkan keadaan force majeur adalah: ${ }^{14}$

1. Adanya kejadian yang tidak terduga;

2. Adanya halangan yang menyebabkan suatu prestasi tidak mungkin dilaksanakan;

3. Ketidakmampuan tersebut tidak disebabkan oleh kesalahan debitur;

4. Ketidakmampuan tersebut tidak dapat dibebankan risiko kepada debitur.

Apabila dicermati, pengaturan mengenai force majeure yang terdapat dalam KUHPerdata tidak terdapat pasal yang mengatur force majeure secara umum untuk suatu kontrak bilateral, sehingga tidak terdapat patokan yuridis secara umum yang

14 Harnowo, Tri, (2020, Maret, 30), Wabah Corona sebagai Alasan Force Majeur dalam Perjanjian, Di akses pada tanggal 25 April 2020, pukul 15:39 WIB., Hukum Online.com., https://www.hukumonline.com/klinik/detail/ulasan/lt5e81ae9a6fc45/wabah-corona-sebagai-alasan-iforcemajeur-i-dalam-perjanjian/. 
dapat digunakan dalam mengartikan apa yang dimaksud dengan force majeure. ${ }^{15}$

Riduan Syahrani menjelaskan overmacht sering juga disebut force majeur yang lazimnya diterjemahkan dengan keadaan memaksa dan ada pula yang menyebut dengan "sebab kahar". ${ }^{16}$ Keadaan memaksa oleh para sarjana hukum klasik diartikan sebagai suatu keadaan yang bersifat mutlak tidak dapat dihindari debitur dalam memenuhi prestasinya terhadap suatu kewajiban. Pikiran mereka hanya tertuju pada bencana alam (act of god) atau kecelakaan-kecelakaan yang berada di luar kemampuan manusia untuk menghindarinya. ${ }^{17}$ Akan tetapi dalam perkembangannya timbul pengertian bahwa overmacht tidak selamanya dan tidak selalu harus bersifat mutlak. ${ }^{18}$

Berdasarkan teori, force majeur dapat dibedakan menjadi dua jenis yaitu force majeure absolut dan force majeure relatif. ${ }^{19}$ Force majeurelovermacht absolut terjadi apabila pemenuhan prestasi itu tidak mungkin (ada unsur imposibilitas) dilaksanakan oleh siapapun juga. Sedangkan force majeure relatif terjadi ketika suatu perjanjian masih mungkin untuk dilaksanakan namun dengan pengorbanan atau biaya yang sangat besar dari pihak debitur. ${ }^{20}$

Apabila dilihat dari segi jangka waktu berlakunya keadaan yang menyebabkan terjadinya force majeure, maka force majeure dapat dibedakan atas: ${ }^{21}$

1. Force majeure permanen

Suatu force majeure dikatakan bersifat permanen jika sama sekali sampai kapan pun suatu prestasi yang terbit dari kontrak tidak mungkin dilakukan lagi.

2. Force majeure temporer

Sebaliknya, suatu force majeure dikatakan bersifat temporer bilamana terhadap pemenuhan prestasi dari kontrak tersebut tidak mungkin dilakukan untuk sementara waktu.

Pengusaha dimungkinkan menggunakan pandemi corona sebagai alasan kahar atauforce majeure untuk melakukan PHK mengingat pengaruhnya yang besar pada kegiatan operasional perusahaan. Terkendalanya kegiatan operasional berdampak terhadap pemasukan perusahaan, akibatnya perusahaan kesulitan dalam membayar upah pekerja yang merupakan kewajibannya. Disamping itu, pandemi

15 Isradjuningtias, Agri, Chairunisa, (2015, _ _ Juni), Force Majeure (Overmacht) Dalam Hukum Kontrak (Perjanjian) Indonesia, Veritas et Justitia, Volume 1, Nomor 1, hlm. 146.

16 Syahrani, Riduan, (2006), Seluk Beluk dan Asas-Asas Hukum Perdata, Bandung: Alumni, hlm. 232.

17 Isradjuningtias, Agri, Chairunisa Op.Cit. hlm. 149.

18 Syahrani, Riduan, Op.Cit., hlm. 235.

19 Subekti, (2002), Pokok-pokok Hukum Perdata. Jakarta: PT. Intermasa, hlm. 150.

20 Badrulzaman, Mariam, Darus, (2015), Hukum Perikatan Dalam KUH Perdata Buku Ketiga (Yurisprudensi, Doktrin, Serta Penjelasan), Bandung: Citra Aditya Bakti, hlm. 35-36.

21 Isradjuningtias, Agri, Chairunisa Op.Cit. hlm. 150. 
corona dapat dikategorikan kedalam peristiwa yang sifatnya tidak terduga karena timbul diluar kekuasaan para pihak sehingga tidak memiliki kemampuan untuk mencegahnya. Bila dilihat dari segi jangka waktu berlakunya keadaan, pandemi corona termasuk kedalam force majeure yang bersifat temporer mengingat ketidaksanggupan pengusaha dalam melaksanakan kewajibannya hanya bersifat sementara sampai keadaan kembali normal.

Adanya kebijakan Pemerintah yang telah menetapkan pandemi corona sebagai bencana nasional serta dikeluarkannya sejumlah produk hukum dapat memperkuat alasan pengusaha untuk menyatakan pandemi corona sebagai suatu peristiwa yang menimbulkan keadaan memaksa (force majeure) karena secara eksplisit menyimpulkan bahwa pandemi corona dikategorikan sebagai bencana nonalam berskala nasional.

Beberapa produk hukum itu seperti Keputusan Presiden Nomor 12 Tahun 2020 tentang Penetapan Bencana Non Alam Penyebaran Corona Virus Disease 2019 (COVID-19) Sebagai Bencana Nasional (selanjutnya disebut Keppres No. 12/2020), Peraturan Pemerintah Nomor 21 Tahun 2020 tentang Pembatasan Sosial Berskala Besar Dalam Rangka Percepatan Penanganan
Corona Virus Disease 2019 (COVID-19) (selanjutnya disebut PP No. 21/2020), Keputusan Presiden Nomor 11 Tahun 2020 tentang Penetapan Kedaruratan Kesehatan Masyarakat Corona Virus Disease 2019 (COVID-19) (selanjutnya disebut Keppres No. 11/2020), dan Undang-Undang Republik Indonesia Nomor 24 Tahun 2007 Tentang Penanggulangan Bencana (selanjutnya disebut UU No. 24/2007). Dalam Pasal 1 angka 3 UU No. 24/2007 menjelaskan bahwa bencana nonalam merupakan bencana yang diakibatkan oleh peristiwa atau rangkaian peristiwa nonalam yang antara lain berupa gagal teknologi, gagal modernisasi, epidemi, dan wabah penyakit.

Rahmat S.S. Soemadipradja dalam pendapatnya menjelaskan bila diperbandingkan dengan lingkup force majeure yang diatur dalam KUHPerdata maka terdapat perkembangan yang terjadi, bahwa lingkup force majeure tidak lagi terbatas pada peristiwa alam atau act of god, dan hilangnya objek yang diperjanjikan, tetapi sudah meluas kepada tindakan administratif penguasa, kondisi politik seperti perang. ${ }^{22}$ Beberapa ruang lingkup atau jenis peristiwa tersebut berdasarkan yurisprudensi dan putusan Mahkamah Agung (MA) meliputi: ${ }^{23}$

\footnotetext{
22 Soemadipradja, Rahmat, S.S, (2010), Penjelasan Hukum tentang Keadaan Memaksa, Jakarta: Nasional Legal Reform Program-Gramedia, hlm. 120.

23 Ibid., hlm. 119.
} 
1. Resiko perang, kehilangan benda objek perjanjian yang disebabkan dari kuasa Yang Maha Besar: disambar halilintar, kebakaran, dirampas tentara Jepang dalam masa perang (Putusan MA RI No. Reg. 15 K/Sip/1957);

2. Act of God, tindakan administratif penguasa, perintah dari yang berkuasa, keputusan, segala tindakan administratif yang menentukan atau mengikat, suatu kejadian mendadak yang tidak dapat diatasi oleh pihak-pihak dalam perjanjian (Putusan MA RI No. 3389 K/Pdt/1984);

3. Peraturan-peraturan pemerintah (Putusan MA RI No. Reg. 24 K/Sip/1958); Keadaan darurat (Putusan MA RI No. Reg. 1180 K/Sip/1971); dan situasi atau keadaan yang sama sekali tidak dapat diduga dan/atau yang sangat memaksa yang terjadi di luar kekuasaan pihak yang harus berprestasi (Putusan No. 21/Pailit/2004/PN.Niaga.Jkt.Pst);

4. Kecelakaan di laut, misalnya kapal tenggelam karena ombak besar memukul lambung kapal (Putusan MA RI No. 409 K/Sip/1983);

5. Keadaan darurat (Putusan MA RI No. Reg. 1180 K/Sip/1971);

6. Situasi atau keadaan yang sama sekali tidak dapat diduga dan/atau yang sangat memaksa yang terjadi di luar kekuasaan pihak yang harus berprestasi (Putusan No. 21/Pailit/2004/PN.Niaga.Jkt.Pst).

Berdasarkan pendapat Rahmat S.S. Soemadipradja dan yurisprudensi tersebut, maka kebijakan serta sejumlah peraturan hukum yang dikeluarkan Pemerintah dalam mengatasi penyebaran pandemi corona termasuk kedalam lingkup atau jenis force majeure. Hal ini sejalan dengan pendapat Abdul Salam yang menilai bahwa force majeure atau keadaan memaksa memiliki dua sifat, yakni umum dan khusus. Force majeure yang sifatnya umum berkaitan dengan act of god, sementara force majeure yang bersifat khusus berhubungan dengan act of human. Peraturan hukum yang dikeluarkan pemerintah Indonesia berkaitan dengan pencegahan pandemi corona masuk dalam kategori force majeure khusus (act of human). ${ }^{24}$

Sementara itu, disisi yang sama Aloysius Uwiyono melihat wabah pandemi corona tergolong sebagai keadaan memaksa (force majeure) karena menyebabkan pengusaha dan buruh (terpaksa) dilarang untuk melaksanakan aktivitas pekerjaannya seperti biasa. ${ }^{25}$ Pandemi corona berdampak terhadap pekerja, pengusaha, dan Pemerintah. Jika dampak pandemi corona menyebabkan

$24 \ldots$ __ (6/4/2020), Bisakah Pengusaha Menjadikan COVID-19 Sebagai Alasan Force Majeure?, Diakses pada tanggal 26 April 2020, pukul 17:37 WIB., Kumparan.com., https://kumparan.com/net_attorney/bisakahpengusaha-menjadikan-covid-19-sebagai-alasan-force-majeure-1tAbHXkk7DC/full,

25 DA, Ady, Thea, (2020, April, 22), Guru Besar Ini Bicara PHK Alasan Force Majeure Dampak Covid-19, Di akses pada tanggal 25 April 2020, Pukul 16:50 WIB, Hukum Online.com., 
perusahaan merugi, sehingga tidak dapat menjalankan produksi, maka dapat dilakukan PHK dengan alasan force majeure. ${ }^{26}$

Lebih lanjut, berdasarkan Pasal 164 ayat (1) UU Ketenagakerjaan menyebutkan bahwa pengusaha dapat melakukan PHK karena perusahaan tutup yang disebabkan perusahaan mengalami kerugian secara terus menerus selama 2 (dua) tahun atau keadaan memaksa (force majeure). Tutupnya perusahaan karena alasan kerugian sebagaimana dimaksud dalam ayat (1) tersebut harus terlebih dulu dibuktikan dengan laporan keuangan 2 (dua) tahun terakhir yang telah diaudit oleh akuntan publik sebagaimana ketentuan Pasal 164 ayat

(2) UU Ketenagakerjaan.

Selain alasan force majeure, tindakan efisiensi juga menjadi alasan yang banyak digunakan oleh pengusaha untuk melakukan PHK ditengah pandemi corona. UU Ketenagakerjaan sendiri tidak menjelaskan apa yang dimaksud dengan "efisiensi". Dalam konteks perusahaan efisiensi adalah hal mengenai upaya perusahaan untuk tidak membuang atau setidak-tidaknya mengurangi pemborosan waktu, tenaga dan biaya dalam menjalankan usaha agar kelangsungan bisnisnya terjaga. Jadi efisiensi merupakan suatu cara yang dilakukan karena alasan ekonomi perusahaan. Dalam kaitannya dengan pekerja, efisiensi dilakukan dengan cara mengurangi jumlah pekerja (retrenchment). ${ }^{27}$

UU Ketenagakerjaan secara eksplisit tidak mengatur boleh/tidaknya perusahaan menggunakan efisiensi sebagai alasan PHK. ${ }^{28}$ Namun, apabila diperhatikan ketentuan Pasal 151 dan 153 UU Ketenagakerjaan dapat diketahui bahwa alasan efisiensi bukan merupakan alasan yang dilarang dalam PHK karena hal efisiensi merujuk kepada persoalan ekonomi yang dihadapi pengusaha. ${ }^{29}$ Selain itu, UU Ketenagakerjaan juga tidak mengatur parameter kondisi/keadaan efisiensi suatu perusahaan.

Beberapa contoh kondisi perusahaan melakukan efisiensi menurut Aria Dipura antara lain seperti adanya kebijakan kantor pusat perusahaan yang terpaksa melakukan perampingan karyawan karena ada krisis ekonomi global (penurunan harga jual/produksi), atau ada peraturan pemerintah

https://www.hukumonline.com/berita/baca/lt5ea02c57c5dc8/guru-besar-ini-bicara-phk-alasan-forcemajeure-dampak-covid-19/.

26 Ibid.

27 Santoso, Budi, (2013,__, Maret) Justifikasi Efisiensi Sebagai Alasan Pemutusan Hubungan Kerja, Mimbar Hukum, Volume 25, Nomor 3, hlm. 411.

28 Ibid.

29 Ibid., hlm. 409-410. 
yang mengharuskan bahwa unit-unit usaha tertentu harus dilebur/dihilangkan. ${ }^{30}$

Efisiensi juga harus didasari oleh alasan yang kuat seperti alat kerja yang jumlahnya tidak sesuai dengan banyaknya pekerja, adanya faktor teknologi atau disebabkan karena kelebihan karyawan. ${ }^{31}$

Disamping itu, dari beberapa perkara yang diselesaikan oleh Mahkamah Agung (MA) seperti perkara Wilson Epson May melawan PT Redpath Indonesia yang telah diputus dengan Putusan MA Nomor 217 K/Pdt.Sus/2010, perkara Arif Maulana Adyasa dkk melawan Standard Chartered Bank Jakarta dengan Putusan MA Nomor 391K/Pdt.Sus/2010, menunjukan bahwa keadaan seperti krisis ekonomi yang kemudian berdampak pada perusahaan serta berkurangnya pekerjaan menjadi kondisi untuk melakukan efisiensi oleh perusahaan. PHK karena alasan efesiensi umumnya dilatarbelakangi oleh adanya tujuan untuk mengurangi beban perusahaan supaya dapat tetap beroperasi.

Dampak pandemi corona tidak hanya menimbulkan ketidakstabilan ekonomi suatu negara bahkan global. Pengaruhnya bahkan hampir terhadap seluruh sektor ekonomi, termasuk aktivitas bisnis perusahaan.
Beberapa kegiatan operasional perusahaan tak dapat berjalan normal bahkan terhenti sepenuhnya, sehingga berdampak pada keuangan dan kemampuan perusahaan. Pandemi corona dan adanya kebijakan pembatasan aktivitas juga menyebabkan turunnya sejumlah permintaan terhadap barang/jasa yang dihasilkan perusahaan, berkurangnya pekerjaan, sehingga menyebabkan terjadinya kelebihan pekerja.

Perusahaan yang tak lagi dapat bertahan dalam mengahadapi dampak pandemi corona kemudian memilih tutup atau menutup sebagaian unit usahanya dan bahkan harus mem-PHK pekerja sebagai bentuk efesiensi sekaligus guna menekan pengeluaran perusahaan agar dapat kembali stabil.

PHK dengan alasan efisiensi dalam UU Ketenagakerjaan diatur dalam Pasal 164 ayat (3) yang menjelaskan bahwa :

"Pengusaha dapat melakukan pemutusan hubungan kerja karena perusahaan tutup bukan karena mengalami kerugian 2 (dua) tahun berturut-turut atau bukan karena keadaan memaksa (force majuer) tetapi perusahaan melakukan efisiensi dengan ketentuan Pekerja berhak atas uang pesangon sebesar 2 (dua) kali ketentuan Pasal 156 ayat (2), uang penghargaan masa kerja sebesar 2 (dua) kali ketentuan Pasal 156 ayat (2), uang penghargaan masa kerja sebesar 1 (satu) kali ketentuan Pasal 156 ayat (3) dan

30 Dipura, Aria. (2020, April), Tinjauan Hukum Mengenai Pemutusan Hubungan Kerja Dengan Alasan Efisiensi, Diakses pada tanggal 29 Mei 2020, pukul 15:01 WIB., www.ybp-law.com, https://www.ybp-law.com/wpcontent/uploads/2020/04/Artikel-PHK-alasan-efisiensi.pdf,.

${ }^{31}$ HariPutri, Ayu, Ratna \& Sonhaji, Solechan, (2016, 30, Maret), Perlindungan Hukum Terhadap Hak-Hak Pekerja Yang Terkena Pemutusan Hubungan Kerja Akibat Efisiensi Perusahaa Berdasarkan Undang-Undang Nomor 13 Tahun 2003 Tentang Ketenagakerjaan di Kota Semarang (Studi Putusan MA Nomor 474/K/Pdt.SusPHI/2013), Diponegoro Law Review, Volume 5, Nomor 2, hlm. 7. 
uang pengganti hak sesuai ketentuan pasal 156 ayat (4)".

Dalam praktik, penerapan ketentuan PHK dengan alasan efisiensi masih menjadi sebuah polemik mengingat terdapat dua penafsiran yang berbeda dalam memaknai ketentuan Pasal 164 ayat (3) UU Ketenagakerjaan tersebut yaitu melakukan efisiensi maka perusahaan dalam kondisi tutup, disisi lain ada yang menafsirkan bahwa perusahaan tidak perlu tutup untuk melakukan efisiensi apabila tindakan perubahan tersebut justru dapat menyelamatkan perusahaan dan sebagian pekerja yang lainnya. ${ }^{32}$

Mahkamah Konstitusi (MK) melalui putusannya Nomor 19/PUU-IX/2011 yang menguji konstitusionalitas Pasal 164 ayat (3) UU Ketenagakerjaan, menafsirkan bahwa ketentuan Pasal 164 ayat (3) bertentangan dengan UUD 1945 sepanjang frasa "perusahaan tutup" tidak dimaknai "perusahaan tutup permanen atau perusahaan tutup tidak untuk sementara waktu”, pada frasa "perusahaan tutup" tidak memiliki kekuatan hukum mengikat sepanjang tidak dimaknai "perusahaan tutup permanen atau perusahaan tutup tidak untuk sementara waktu". 33
Berdasarkan putusan MK tersebut, jelas bahwa kata "efisiensi" yang tercantum dalam ketentuan Pasal 164 ayat (3) UU Ketenagakerjaan tidak serta-merta menjadi dasar bagi perusahaan untuk melakukan PHK terhadap pekerja atau dengan cara mengefisienkan biaya tenaga kerja dengan cara mem-PHK pekerja yang ada. Melainkan harus dimaknai bahwa PHK hanya boleh dilakukan oleh perusahaan terdampak pandemi corona apabila perusahaan tutup, dan tutupnya perusahaan adalah sebagai bentuk efisiensi.

Meskipun MK telah menetapkan pendiriannya mengenai ketentuan Pasal 164 ayat (3) tersebut, namun dalam praktik pada lembaga Mahkamah Agung (MA) masih terdapat kontradiksi tersendiri. Hal itu tampak dalam beberapa putusan yang dikeluarkan Mahkamah Agung seperti putusan MA Nomor 391 K/Pdt.Sus/2010, Putusan MA Nomor 217 K/Pdt.Sus/2010 dan Putusan Nomor 881 K/Pdt.Sus-PHI/2016.

Dalam putusan tersebut, hakim cenderung menerima PHK karena alasan efisiensi tanpa perusahaan tersebut tutup. Hal ini bertujuan guna mempertahankan kelangsungan kegiatan operasional perusahaan. Hakim menilai bahwa pengusaha tidak mungkin

32 Ferianto \& Darmanto, (2010), Himpunan Putusan Mahkamah Agung dalam Perkara PHI Pemutusan Hubungan kerja (PHK) Disertai Ulasan Hukum, Jakarta: PT Raja Grafindo Persada, hlm. 263.

33 Hasan, Bimo, Prasetio dan Mohamad Toha (2020, 1, April,), Dapatkah Perusahaan Melakukan PHK Karena Kerugian Akibat Pandemi Covid-19?, Diakses, pada tanggal 24 April 2020, pukul 21:33 WIB., bplawyers.co.id., https://bplawyers.co.id/2020/04/01/dapatkah-perusahaan-melakukan-phk-karena-kerugianakibat-pandemi-covid-19/. 
membiarkan bisnisnya jatuh tanpa dilakukannya upaya-upaya penyelamatan, termasuk efisiensi biaya pekerja. ${ }^{34}$

Sementara itu, PHK karena alasan efesiensi hanya boleh diambil perusahaan sebagai bentuk langkah terakhir dengan terlebih dahulu menempuh upaya-upaya sebagaimana ketentuan Surat Edaran Menteri Tenaga Kerja dan Transmigrasi Nomor SE907/MEN/PHIPPHI/X/2004 tentang

Pencegahan Pemutusan Hubungan Kerja Massal (selanjutnya disebut SE907/MEN/PHIPPHI/X/2004), yaitu:

1. mengurangi upah dan fasilitas pekerja tingkat atas, misalnya tingkat manajer dan direktur;

2. mengurangi shift;

3. membatasi/menghapuskan kerja lembur;

4. mengurangi jam kerja;

5. mengurangi hari kerja;

6. meliburkan atau merumahkan pekerja/buruh secara bergilir untuk sementara waktu;

7. tidak atau memperpanjang kontrak bagi pekerja yang sudah habis masa kontraknya;

8. Memberikan pensiun bagi yang sudah memenuhi syarat.
Perlindungan Hak Pekerja Yang Diputus Hubungan Kerjanya Oleh Perusahaan Menurut Ketentuan UU Ketenagakerjaan

PHK merupakan suatu peristiwa yang tidak diharapkan terjadinya, terutama dari kalangan buruh/pekerja karena dengan PHK buruh/pekerja yang bersangkutan akan kehilangan mata pencaharian untuk menghidupi diri dan keluarganya, karena itu semua pihak yang terlibat dalam hubungan industrial baik pengusaha, pekerja/buruh, atau Pemerintah, dengan segala upaya harus mengusahakan agar jangan terjadi pemutusan hubungan kerja. ${ }^{35}$

Pasal 1 angka 25 UU Ketenagakerjaan, mendefenisikan PHK sebagai bentuk pengakhiran hubungan kerja karena suatu hal tertentu yang mengakibatkan berakhirnya hak dan kewajiban antara pekerja/buruh dan pengusaha. Ketentuan tersebut terjadi setelah adanya penetapan dari lembaga penyelesaian perselisihan perburuhan seperti mediator, konsiliator, atau Pengadilan Hubungan Industrial (PHI).

Ketika PHK terjadi, UU Ketenagakerjaan sebagai ketentuan pokok telah memberikan perlindungann hukum mengenai hak-hak pekerja yang mengalami PHK. di antaranya yaitu Pasal 156 ayat (1) yang menyebutkan bahwa dalam hal terjadi pemutusan hubungan kerja (PHK), pengusaha

\footnotetext{
34 Santoso, Budi, Op.Cit., hlm. 409

35 Husni, Lalu, (2004), Penyelesaian perselisihan Hubungan Industrial Melalui Pengadilan dan di Luar Pengadilan, PT, Jakarta: Rajagrafindo Persada, hlm. 195.
} 
diwajibkan membayar uang pesangon dan atau uang penghargaan masa kerja dan uang penggantian hak yang seharusnya diterima. Terkait dengan perlindungan hukum terhadap pekerja yang mengalami pemutusan hubungan kerja karena alasan force majeure, pengaturan terkait dengan hal itu sudah diatur dalam Pasal 164 ayat (1) yang menyebutkan bahwa:

"Pengusaha dapat melakukan pemutusan hubungan kerja terhadap pekerja/buruh karena perusahaan tutup yang disebabkan perusahaan mengalami kerugian secara terus menerus selama 2 (dua) tahun, atau keadaan memaksa (force majeure), dengan ketentuan pekerja/buruh berhak atas uang pesangon sebesar 1 (satu) kali ketentuan Pasal 156 ayat (2) uang penghargaan masa kerja sebesar 1 (satu) kali ketentuan Pasal 156 ayat (3) dan uang penggantian hak sesuai ketentuan Pasal 156 ayat (4).”

Menurut Aloysius Uwiyono, bila PHK yang dilakukan oleh perusahaan disebabkan karena perusahaan tutup disebabkan mengalami kerugian atau keadaan memaksa (force majeure), maka mengenai hak-hak pekerja berlaku ketentuan Pasal 164 ayat (1) UU Ketenagakerjaan. ${ }^{36}$ Ketentuan tersebut hanya berlaku apabila alasan untuk melakukan PHK karena perusahaan tutup yang disebabkan oleh perusahaan mengalami kerugian secara terus menerus selama 2 (dua) tahun; atau karena keadaan memaksa (force majeur). Sehingga dengan alasan dan sebab tersebut pekerja/buruh berhak atas uang pesangon sebesar 1 (satu) kali ketentuan Pasal 156 ayat (2), uang penghargaan masa kerja sebesar 1 (satu) kali ketentuan Pasal 156 ayat (3) dan uang penggantian hak sesuai ketentuan Pasal 156 ayat (4). ${ }^{37}$

Sementara itu, terhadap pekerja yang mengalami PHK dengan alasan kepentingan efisiensi maka berlaku ketentuan Pasal 164 ayat (3) UU Ketenagakerjaan yaitu:

"Pengusaha dapat melakukan pemutusan hubungan kerja terhadap Pekerja/buruh karena perusahaan tutup bukan karena mengalami kerugian 2 (dua) tahun berturut-turut atau bukan karena keadaan memaksa (force majeure) tetapi perusahaan melakukan efisiensi, dengan ketentuan Pekerja/buruh berhak atas uang pesangon sebesar 2 (dua) kali ketentuan Pasal 156 ayat (2), uang penghargaan masa kerja sebesar (satu) kali ketentuan Pasal 156 ayat (3) dan uang penggantian hak sesuai ketentuan Pasal 156 ayat (4)".

Mengenai perhitungan uang kompensasi PHK yang menjadi hak pekerja sebagaimana ketentuan Pasal 156 ayat (2), (3), dan (4) tersebut meliputi uang pesangon yaitu pembayaran dalam bentuk uang dari pengusaha kepada buruh/pekerja sebagai akibat adanya PHK yang jumlahnya disesuaikan dengan masa kerja buruh/pekerja

\footnotetext{
36 DA, Ady, Thea Loc.Cit.

37 Putra, Andika, Pramana, ( 2018,__ Juli), Kajian Hukum Terhadap Putusan Mahkamah Agung Atas Perkara No.825k/Pdt.Sus-Phi/2015 Tentang Pemutusan Hubungan Kerja Karena Alasan Efisiensi, Jurnal Hukum Adigama, Volume 1, Nomor 1, hlm. 19.
} 
yang bersangkutan, ${ }^{38}$ sebagaimana ketentuan Pasal 156 ayat (2) UU Ketenagakerjaan.

Disamping itu, pekerja juga berhak atas uang penghargaan masa kerja yaitu uang penghargaan yang diberikan pengusaha kepada pekerja yang dikaitkan dengan lamanya masa kerja, ${ }^{39}$ yang diatur dalam Pasal 156 ayat (3) UU Ketenagakerjaan dan berhak atas uang penggantian hak sebagaimana ketentuan Pasal 156 ayat (4) UU Ketenagakerjaan yaitu uang pembayaran dari pengusaha kepada pekerja sebagai penggantian istirahat tahunan, istirahat panjang, biaya perjalanan ke tempat di mana pekerja diterima bekerja, fasilitas pengobatan, fasilitas perumahan, dan lainnya sebagai akibat PHK. ${ }^{40}$

\section{KESIMPULAN}

1. Pengusaha dimungkinkan menggunakan pandemi corona sebagai alasan force majeure untuk melakukan PHK, mengingat pengaruhnya yang besar pada kegiatan operasional perusahaan. Disamping itu, pandemi corona juga dikategorikan sebagai peristiwa force majeure mengingat sifatnya tidak terduga karena timbul diluar kekuasaan para pihak. Adanya kebijakan Pemerintah yang menetapkan pandemi corona sebagai bencana nasional serta dikeluarkannya sejumlah peraturan hukum memperkuat alasan pengusaha untuk menyatakan pandemi corona sebagai suatu peristiwa force majeure karena secara eksplisit menyimpulkan pandemi corona dikategorikan sebagai bencana nonalam berskala nasional. Selain alasan force majeure, efisiensi juga menjadi alasan untuk melakukan PHK, namun dalam praktek hal ini masih menjadi sebuah polemik mengingat terdapat dua penafsiran yang berbeda dalam memaknai ketentuan Pasal 164 ayat (3) UU Ketenagakerjaan. Apabila didasarkan pada putusan MK Nomor 19/PUU-IX/2011, PHK dengan alasan efesiensi boleh dilakukan oleh perusahaan terdampak pandemi corona apabila perusahaan tutup secara permanen atau tutup tidak untuk sementara waktu, dan tutupnya perusahaan adalah sebagai bentuk efisiensi. Disamping itu, perusahaan juga terlebih dahulu telah menempuh upaya-upaya sebagaimana ketentuan SE-907/MEN/PHIPPHI/X/2004.

2. PHK berimplikasi pada lahirnya kewajiban pengusaha untuk membayar hak-hak pekerja. Jika PHK yang

\footnotetext{
38 Husni, Lalu, (2014), Pengantar Hukum Ketenagakerjaan, Edisi Revisi, Jakarta: Rajagrafindo Persada, hlm. 186.

39 Khakim, Abdul, (2014), Dasar-Dasar Hukum Ketenagakerjaan Indonesia, Cet. Ke-4 Edisi Revisi, Bandung: Citra Aditya Bakti, hlm. 203.

40 Ibid.
} 
dilakukan pengusaha disebabkan oleh alasan force majeure maka berdasarkan Pasal 164 ayat (1) pekerja berhak atas uang pesangon sebesar 1 (satu) kali ketentuan Pasal 156 ayat (2) uang penghargaan masa kerja sebesar 1 (satu) kali ketentuan Pasal 156 ayat (3) dan uang penggantian hak sesuai ketentuan Pasal 156 ayat (4). Sedangkan apabila PHK yang dilakukan perusahaan karena alasan efisiensi maka berdasarkan ketentuan Pasal 164 ayat (3) perusahaan wajib membayar hak pekerja yang terdiri dari uang pesangon sebesar 2 (dua) kali ketentuan Pasal 156 ayat (2), uang penghargaan masa kerja sebesar (satu) kali ketentuan Pasal 156 ayat (3) dan uang penggantian hak sesuai ketentuan Pasal 156 ayat (4).

\section{DAFTAR PUSTAKA}

\section{Peraturan Perundang-Undangan}

Undang-Undang Dasar Negara Republik Indonesia Tahun 1945

Undang-Undang Nomor 13 Tahun 2003 Tentang Ketenagakerjaan

Kitab Undang-Undang Hukum Perdata

Undang-Undang Republik Indonesia Nomor 24 Tahun 2007 Tentang Penanggulangan Bencana

Peraturan Pemerintah Nomor 21 Tahun 2020 tentang Pembatasan Sosial Berskala Besar Dalam Rangka Percepatan Penanganan Corona Virus Disease 2019 (COVID-19)

Keputusan Presiden Nomor 11 Tahun 2020 tentang Penetapan Kedaruratan Kesehatan Masyarakat Corona Virus Disease 2019 (COVID-19)
Peraturan Menteri Kesehatan Republik Indonesia Nomor 9 Tahun 2020 tentang Pedoman Pembatasan Sosial Berskala Besar Dalam Rangka Percepatan Penanganan Corona Virus Disease (COVID-19)

Keputusan Presiden Nomor 12 Tahun 2020 tentang Penetapan Bencana Non Alam Penyebaran Corona Virus Disease (COVID-19) Sebagai Bencana Nasional

Surat Edaran Menteri Tenaga Kerja dan Transmigrasi Nomor SE907/MEN/PHIPPHI/X/2004 tentang Pencegahan Pemutusan Hubungan Kerja Massal

\section{Buku-Buku}

Asikin, Zainal dkk, (2004), Dasar-Dasar Hukum Perburuhan, Jakarta: Rajagrafindo Persada.

Badrulzaman, Mariam, Darus (2015), Hukum Perikatan Dalam KUH Perdata Buku Ketiga (Yurisprudensi, Doktrin, Serta Penjelasan), Bandung: Citra Aditya Bakti.

Ferianto \& Darmanto, (2010), Himpunan Putusan Mahkamah Agung dalam Perkara PHI Pemutusan Hubungan kerja (PHK) Disertai Ulasan Hukum, Jakarta: PT Raja Grafindo Persada.

Husni, Lalu, (2014), Pengantar Hukum Ketenagakerjaan, Edisi Revisi, Jakarta: Rajagrafindo Persada. ,(2004),Penyelesaian perselisihan

Hubungan Industrial Melalui Pengadilan dan di Luar Pengadilan, PT, Jakarta: Rajagrafindo Persada.

Khakim, Abdul, (2014), Dasar-Dasar Hukum Ketenagakerjaan Indonesia, Cet. Ke-4 Edisi Revisi, Bandung: Citra Aditya Bakti.

Soemadipradja, Rahmat, S.S. (2010), Penjelasan Hukum tentang Keadaan Memaksa, Jakarta: Nasional Legal Reform Program-Gramedia.

Soepomo, Imam, (2003), Hukum Perburuhan Bidang Hubungan Kerja, Jakarta: Djambatan. 
Subekti. (2002), Pokok-pokok Hukum Perdata. Jakarta: PT. Intermasa.

Syahrani, Riduan, (2006), Seluk Beluk dan Asas-asas Hukum Perdata, Bandung: Alumni.

\section{Jurnal}

HariPutri, Ayu, Ratna dan Sonhaji, Solechan, (2016, 30, Maret), Perlindungan Hukum Terhadap Hak-Hak Pekerja Yang Terkena Pemutusan Hubungan Kerja Akibat Efisiensi Perusahaa Berdasarkan Undang-Undang Nomor 13 Tahun 2003 Tentang Ketenagakerjaan di Kota Semarang (Studi Putusan MA Nomor 474/K/Pdt.Sus-PHI/2013),

Diponegoro Law Review, Volume 5, Nomor 2.

Isradjuningtias, Agri, Chairunisa (2015, Juni), Force Majeure (Overmacht) Dalam Hukum Kontrak (Perjanjian) Indonesia, Veritas et Justitia, Volume 1, Nomor 1.

Kasim, Umar (2004), Hubungan Kerja Dan Pemutusan Hubungan Kerja, Informasi Hukum, Volume 2.

Maringan, Nikodemus, (2015), Tinjauan Yuridis Pelaksanaan Pemutusan Hubungan Kerja (PHK) Secara Sepihak Oleh Perusahaan Menurut Undang-Undang No. 13 Tahun 2003 Tentang Ketenagakerjaan, Jurnal Ilmu Hukum Legal Opinion, Edisi 3, Volume 3, Nomor 3.

Putra, Anak Agung Ngurah Wisnu Manika dkk, (2018, 24, Oktober) Perlindungan Hukum Bagi Pekerja Yang Mengalami Pemutusan Hubungan Kerja Oleh Pemberi Kerja Karena Force Majeure, Kertha Semaya, Volume 5 , Nomor 1.

Putra, Andika, Pramana ( 2018, Juli), Kajian Hukum Terhadap Putusan Mahkamah Agung Atas Perkara
No.825k/Pdt.Sus-Phi/2015 Tentang Pemutusan Hubungan Kerja Karena Alasan Efisiensi, Jurnal Hukum Adigama, Volu me 1, Nomor 1.

Randi, Yusuf, (2020, 1, Maret), Penerapan Perjanjian Bersama Berupa Pemberian Kompensasi Pemutusan Hubungan Kerja Yang Bertentangan Dengan Undang-Undang Ketenagakerjaan, Jurnal Hukum De'rechtsstaat, Volume 6, Nomor 1.

Santoso, Budi, (2013, Maret) Justifikasi Efisiensi Sebagai Alasan Pemutusan Hubungan Kerja", Mimbar Hukum, Volume 25, Nomor 3.

Yuliana ,(2020, Februari), Corona Virus disease (Covid-19); Sebuah Tinjauan Literatur, Wellness and healthy magazine, Volume 2, Nomor 1.

\section{Internet}

DA, Ady, Thea, (2020, April, 22), Guru Besar Ini Bicara PHK Alasan Force Majeure Dampak Covid-19, Di akses dari https://www.hukumonline.com/berita /baca/lt5ea02c57c5dc8/guru-besarini-bicara-phk-alasan-force-majeuredampak-covid-19/, pada tanggal 25 April 2020.

Dipura, Aria, (2020, April), Tinjauan Hukum Mengenai Pemutusan Hubungan Kerja Dengan Alasan Efisiensi, Diakses dari https://www.ybplaw.com/wpcontent/uploads/2020/04/ArtikelPHK-alasan-efisiensi.pdf, Pada tanggal 29 Mei 2020.

Harnowo, Tri, (2020, Maret, 30,), Wabah Corona sebagai Alasan Force Majeur dalam Perjanjian",di akses dari https://www.hukumonline.com/klini $\mathrm{k} /$ detail/ulasa n/lt5e81ae9a6fc45/wabah-coronasebagai-alasan-iforce-majeur-i- 
dalam-perjanjian/ pada tanggal 25 April 2020.

Hasan, Bimo, Prasetio dan Mohamad Toha (2020, April, 1), Dapatkah Perusahaan Melakukan PHK Karena Kerugian Akibat Pandemi Covid-19?, Diakses dari https://bplawyers.co.id/2020/04/01/d apatkah-perusahaan-melakukan-phkkarena-kerugian-akibat-pandemicovid-19/ , Pada tanggal 24 April 2020.

https://www.cnnindonesia.com/internasional /20200417065915-113494382/update-corona-global-21juta-terinfeksi-546-ribu-sembuh, Di akses pada tanggal 20 April 2020.

https://www.cnnindonesia.com/nasional/202 00420133516-20-495244/updatecorona-20-april-6760-positif-747sembuh, Di akses pada tanggal 20 April 2020.

https://www.hukumonline.com/berita/baca/lt 5e8edae3d0c9f/menaker--phklangkah-terakhir-hadapi-dampakcovid-19/, Di akses pada tanggal 23 April 2020.

https://kemnaker.go.id/news/detail/menakerbadai-pasti-berlalu-panggil-kembalipekerja-yang-ter-phk-nanti, Diakses pada tanggal 23 April 2020.

https://kumparan.com/net_attorney/bisakahpengusaha-menjadikan-covid-19sebagai-alasan-force-majeure1tAbHXkk7DC/full, Diakses pada tanggal 26 April 2020.

Siregar, Putra, PM \& Ajeng Hanifa Zahra, (2020, April, 15,), Bencana Nasional Penyebaran COVID-19 sebagai Alasan Force Majeure, Apakah Bisa?, Di akses dari https://www.djkn.kemenkeu.go.id/art ikel/baca/13037/Bencana-NasionalPenyebaran-COVID-19-sebagai-
Alasan-Force-Majeure-Apakah-

Bisa.html, pada tanggal 21 April 2020 